\title{
MARKET INTEGRATION OF CORN (Zea mays) IN TUBAN DISTRICT
}

\author{
Inong Hasti Yunika*, Ratya Anindita, Putri Budi Setyowati
}

Agricultural Economics Departement, Brawijaya University

*corresponding author: inonghastiyunika@gmail.com

\begin{abstract}
Market integration is one indicator of marketing efficiency, especially price efficiency, which is a measure that shows the extent to which price changes that occur in the reference market will cause changes that occur in market followers. The difference in prices received by farmers, wholesalers, and retailers in Indonesia in 2011-2015 has increased and decreased by an unequal amount, which means that price changes among marketing agents are not balanced. Agribusiness market participants currently do not use market communication information system services on time so that it will cause information asymmetry and indicate that the market is not integrated. This study analyzes market integration based on the relationship between corn prices at the level of producers, wholesalers, and retailers. The analytical methods used are Engle-Granger cointegration, Error Corection Model (ECM), and Granger Causality Test. The results show that the corn market between producers and wholesalers, between wholesalers and retailers, and between producers and retailers has been integrated in the long and short term. Market information needs to be improved so that market integration is stronger.
\end{abstract}

Keywords: corn, market integration, Engle-Granger cointegration, Error Corection Model (ECM), Granger Causality test

\section{INTRODUCTION}

The use of corn as raw material for animal feed is difficult to replace with other ingredients. Evidently in 2017 the demand for corn for animal feed ingredients rose by 6-8\% (Pioneer, 2017). Indonesia exports and imports maize commodities. Corn exports are carried out when local maize production is abundant which causes local corn prices to decline (Murdaningsih, 2018). Whereas corn imports are carried out during famine which causes local corn prices to rise (Revania, 2014). The corn trade balance shows a negative value, which means that imports are higher than exports. The large volume of imports shows that domestic corn production has not been able to meet demand. This caused Indonesia to increase corn production.

Corn production during the period of 2011 to 2015 experienced positive growth. While Indonesian corn consumption in households and the feed industry in 2011 to 2015 tends to fluctuate. Changes in supply and demand can cause prices to vary. The development of corn prices for producers and consumers in 2011 to 2015 fluctuated with an average growth of $6.21 \%$ in producers and $9.05 \%$ in consumers (Badan Pusat Statistik, 2016). The average growth of corn prices that are not the same shows that the price changes between producers and consumers are not balanced. An imbalance needs to be analyzed by market integration between corn marketing agencies.

Market integration is a method used to analyze the integration of prices between markets (Zunaidah et al., 2015). Market integration is intended to answer information that is closely related to changes in prices at the producer level, marketing institutions, and consumers (Asmara and Ardhiani, 2010). Market integration analysis can describe the effectiveness and behavior of commodity markets at the level of producers and consumers who have demand and supply forces (Simatupang and Situmorang, 1988). Based on the above problems, this study aims to determine the integration of the corn market between producers and wholesalers, the integration of the corn market between wholesalers 
and retailers, and the integration of the corn market between producers and retailers.

\section{RESEARCH METHODS}

\section{a. Location Determination}

The selection of the location of this research was conducted purposively based on data from the Central Statistics Agency (BPS), the Agriculture Service of Tuban Regency, and the Office of Cooperative Industry and Trade in Tuban Regency. Determining this location is done by considering that Tuban Regency is one of the highest nationallevel corn producing regions (Badan Pusat Statistik, 2016).

\section{b. Data Type}

\begin{tabular}{lll}
\hline \multicolumn{1}{c}{ Data Type } & \multicolumn{1}{c}{ Source } \\
\hline $\begin{array}{l}\text { Corn prices at the } \\
\text { producer level }\end{array}$ & 1. & $\begin{array}{l}\text { Central Bureau of } \\
\text { Statistics (BPS) } \\
\text { Agriculture office of } \\
\text { Corn prices at the } \\
\text { wholesaler level }\end{array}$ \\
$\begin{array}{l}\text { Tuban Regency, } \\
\text { Corn prices at the } \\
\text { retailer level }\end{array}$ & $\begin{array}{l}\text { The Cooperative } \\
\text { Industry Office and } \\
\text { Trade in Tuban } \\
\text { Regency }\end{array}$ \\
\hline
\end{tabular}

\section{c. Data Stationarity Test}

The stationary data test is carried out to determine the stationarity of the model whether it is at the level of the level or at the level of the first difference. According to Gujarati (2006) Stationarity tests can be used in various ways. But the stationarity test this time uses a rather new test, namely the unit root test (unit root test) through the Dickey-Fuller (DF) test. Research using DF this test can be formulated in the following equation:

$$
\mathrm{P}_{\mathrm{t}}=\rho_{\mathrm{a}} \mathrm{P}_{\mathrm{t}-1}+u_{t}
$$

Where ut $\approx \prod \mathrm{D}(0, \sigma 2)$, with the null hypothesis $\mathrm{H}_{0}: \rho_{\mathrm{a}}=1$ against $\mathrm{H}_{1}: \rho_{\mathrm{a}}<1$. If the time series data is nonstationary, then a two-step procedure is performed to evaluate the requirements for the equation. The first step taken is the Augmented Dickey Fuller (ADF) test for order 1:

$$
\Delta \mathrm{P}_{\mathrm{t}}=\beta_{1}+\beta_{2} \mathrm{t}+\delta \mathrm{P}_{\mathrm{t}-1}+\alpha_{1} \sum_{i=1}^{M} \Delta P_{t-1}+\mu_{\mathrm{t}}
$$

This equation is an intercept model where $\beta 1$ and $\beta 2$ are trends.

Where:

$\Delta \mathrm{P}_{\mathrm{t}} \quad: \mathrm{P}_{\mathrm{t}}-\mathrm{P}_{\mathrm{t}-1}$ as the difference unit

$\mathrm{P}_{\mathrm{t}} \quad$ : variable price of corn at each market level in the $\mathrm{t}$-period $(\mathrm{Rp} / \mathrm{kg})$
$\mathrm{P}_{\mathrm{t}-1} \quad$ : variable price of corn at each market level in the t-period minus the lag or value in the previous period $(\mathrm{Rp} / \mathrm{kg})$

t $\quad$ : trend variable or time

$\beta_{1} \quad$ : intersept

$\alpha, \beta, \delta \quad:$ coefficients

$\mu_{\mathrm{t}} \quad$ : error term

The hypotheses used in this test method are:

$\mathrm{H}_{0} \quad: \delta \geq 0$, (time series is unit root and not stationary)

$\mathrm{H}_{1} \quad: \delta<0$, (time series is stationary)

If in operation on the first nonstationary difference, then the second difference operation is made to:

$$
\Delta^{2}\left(\mathrm{P}_{\mathrm{t}}\right)=\Delta\left(\Delta \mathrm{P}_{\mathrm{t}}\right)
$$

If the first step produces two nonstationary groups, the two are integrated order 1 . Then the second step generates stationary Ut so that the two groups are said to be cointegrated on the order $(1,1)$.

\section{d. Engle-Granger Cointegration Test}

Steps to be taken for non-stationary time series price data at the leve level are the Engle-Granger Cointegration Test. The Engle-Granger Cointegration Test is used to see if there is cointegration between the two data. Cointegration test aims to determine whether there is a long-term relationship or balance relationship between the dependent variable and the independent variable or in other words that two or more variables are said to be cointegrated if they have long-term relationships or balance. The cointegration test equation is as follows:

a. Selling prices of corn at the farm level and wholesale traders

$\mathrm{HP}_{\mathrm{t}}=\beta_{0}+\beta_{1} \mathrm{HG}_{\mathrm{t}}+\mathrm{e}_{\mathrm{t}}$

b. The selling price of corn at the level of wholesalers and retailers

$\mathrm{HG}_{\mathrm{t}}=\beta_{0}+\beta_{1} \mathrm{HK}_{\mathrm{t}}+\mathrm{e}_{\mathrm{t}}$

c. Selling prices of corn at the farm level and retailers

Where:

$$
\mathrm{HP}_{\mathrm{t}}=\beta_{0}+\beta_{1} \mathrm{HK}_{\mathrm{t}}+\mathrm{e}_{\mathrm{t}}
$$

$\mathrm{HP}$ : Corn price at farm level (Rp. / Kg)

HG : The price of corn at the wholesaler level (Rp. / Kg)

HK : The price of corn at the retailer's level (Rp. / $\mathrm{Kg}$ )

$\beta_{0} \quad$ : Constants

$\beta_{1} \quad$ : Regression coefficient

$\mathrm{e}_{\mathrm{t}} \quad$ : error term

Hypothesis:

$\mathrm{H}_{0} \quad$ : $\mathrm{e}_{\mathrm{t}}$ is not stationary (between HP with HG not cointegrated, $\mathrm{HG}$ with $\mathrm{HK}$ not cointegrated, or HP with HK not 
cointegrated); probability value> $10 \%$ or 0.1 then $\mathrm{H} 0$ is accepted.

$\mathrm{H}_{1} \quad \mathrm{e}_{\mathrm{t}}$ stationary (between HP with cointegrated $\mathrm{HG}, \mathrm{HG}$ with cointegrated HK, or HP with cointegrated HK);

\section{e. Error Correction Model (ECM)}

ECM is a testing method used to find a balance model in short-term relationships to long-term. According to Granger Representation Theorem, if there are two variables, cointegration occurs, then these two variables can be expressed in ECM (Anindita and Baladina, 2017). In general, the ECM model can be formulated as follows:

$\Delta \mathrm{HP}_{\mathrm{t}}=\alpha_{0}+\alpha_{1} \Delta \mathrm{HG}_{\mathrm{t}}+\alpha_{2} \mathrm{ECT}_{\mathrm{t}}+\mu_{\mathrm{t}}$

$\Delta \mathrm{HG}_{\mathrm{t}}=\alpha_{0}+\alpha_{1} \Delta \mathrm{HK}_{\mathrm{t}}+\alpha_{2} \mathrm{ECT}_{\mathrm{t}}+\mu_{\mathrm{t}}$

$\Delta \mathrm{HP}_{\mathrm{t}}=\alpha_{0}+\alpha_{1} \Delta \mathrm{HK}_{\mathrm{t}}+\alpha_{2} \mathrm{ECT}_{\mathrm{t}}+\mu_{\mathrm{t}}$

Where:

$\mathrm{HP}_{\mathrm{t}} \quad$ : selling price at farm level at period $\mathrm{t}$ (time)

$\mathrm{HG}_{\mathrm{t}} \quad$ : selling price at wholesaler level in period $\mathrm{t}$ (time)

$\mathrm{HK}_{\mathrm{t}}$ : the selling price at the retailer's level in the period $t$ (time)

$\alpha_{0} \quad$ : constants
$\Delta \quad$ : price changes

ECT : error correction term

$\mu_{\mathrm{t}} \quad$ : error term

\section{f. Granger Causality Test}

Granger causality test is used to determine the effect or relationship of interaction on each variable between one variable to another. Testing of granger causality in this study is only done by comparing the probability value with just the level of trust. The research hypothesis is $\mathrm{H} 0$ : probability value > 0.05 means there is no causality relationship between variables with each other. $\mathrm{H} 1$ : probability value $<0.05$ means there is a causality relationship between variables with each other

\section{RESULTS AND DISCUSSION}

\section{A. Corn Price Data Stationarity Test in Tuban Regency}

The results of the stationary price testing of corn at the producer level, the level of wholesalers, and the level of retailers are shown in Table 1.

Table 1. Stationary Results of Corn Selling Price Data at the Producer Level

\begin{tabular}{cccccccccc}
\hline \multirow{2}{*}{ Variable } & \multicolumn{2}{c}{ Level } & \multicolumn{3}{c}{ Critical Value } & \multicolumn{2}{c}{ Probability } & \multicolumn{2}{c}{ Information } \\
\cline { 2 - 9 } & Level & FD & $1 \%$ & $5 \%$ & $10 \%$ & Level & FD & Level & FD \\
\hline HP & $-2,97$ & $-8,21$ & $-4,07$ & $-3,46$ & $-3,16$ & 0,1459 & 0,0000 & NS & S \\
HPG & $-3,13$ & $-9,33$ & $-4,07$ & $-3,46$ & $-3,16$ & 0,1059 & 0,0000 & NS & S \\
HPP & $-2,65$ & $-7,89$ & $-4,07$ & $-3,46$ & $-3,16$ & 0,2603 & 0,0000 & NS & S \\
\hline
\end{tabular}

Source: Secondary data (processed)

Information:

$\mathrm{HP}=$ Manufacturer Price

HPG $\quad=$ Price of Wholesale Traders

HPP $\quad=$ Price of Retailers

FD $\quad=$ First Difference (First difference)

$\mathrm{S} \quad=$ Stationary

NS $\quad=$ Not Stationary

The results of the analysis in table 1 show that the data on corn prices at the producer level, the level of wholesalers, and the level of retailers at the level of the level are not stationary so cointegration tests are needed. Cointegration is a concept in econometrics which shows the phenomenon of compatibility of fluctuations in some data for a certain period of time. The economic interpretation of cointegration is that if two or more series form a long-term equilibrium relationship, then even though each of these series is not stationary, the series is paraded together over time and their differences will be stable.

\section{B. Engle Granger Cointegration Test}

Engle Granger's Cointegration Test results at the producer level with wholesalers, the level of wholesalers with retailers, and the producer level with retailers are shown in Table 2.

Table 2. Corn Price Cointegration Results

\begin{tabular}{lccccccccc}
\hline \multirow{2}{*}{ Variabel } & \multicolumn{2}{c}{ Level } & \multicolumn{3}{c}{ Critical Value } & \multicolumn{2}{c}{ Probability } & \multicolumn{2}{c}{ Information } \\
\cline { 2 - 10 } & Level & FD & $1 \%$ & $5 \%$ & $10 \%$ & Level & FD & Level & FD \\
\hline HP and & $-3,20$ & $-11,3$ & $-4,07$ & $-3,46$ & $-3,16$ & 0,0905 & 0,0000 & $\mathrm{~S}$ & $\mathrm{~S}$ \\
HPG & & & & & & & & &
\end{tabular}

Source: Secondary Data (processed) 
Table 3. Advanced Corn Price Cointegration Results

\begin{tabular}{|l|c|c|c|c|c|c|c|c|c|}
\hline \multirow{2}{*}{ Variabel } & \multicolumn{2}{|c|}{ Level } & \multicolumn{3}{c|}{ Critical Value } & \multicolumn{2}{c|}{ Probability } & \multicolumn{2}{c|}{ Information } \\
\cline { 2 - 10 } & Level & FD & $1 \%$ & $5 \%$ & $10 \%$ & Level & FD & Level & FD \\
\hline $\begin{array}{l}\text { HPG and } \\
\text { HPP }\end{array}$ & $-5,29$ & $-13,2$ & $-4,07$ & $-3,46$ & $-3,16$ & 0,0002 & 0,0000 & $\mathrm{~S}$ & $\mathrm{~S}$ \\
\hline $\begin{array}{l}\text { HP and } \\
\text { HPP }\end{array}$ & $-2,72$ & $-8,6$ & $-4,07$ & $-3,46$ & $-3,16$ & 0,2286 & 0,0000 & NS & $\mathrm{S}$ \\
\hline
\end{tabular}

Source: Secondary Data (processed)

Information:

$\begin{array}{ll}\mathrm{HP} & =\text { Manufacturer Price } \\ \mathrm{HPG} & =\text { Price of Wholesale Traders } \\ \mathrm{HPP} & =\text { Price of Retailers } \\ \text { FD } & =\text { First Difference (First difference) } \\ \mathrm{S} & =\text { Stationary } \\ \text { NS } & =\text { Not Stationary }\end{array}$

The Engle Granger cointegration test in Table 2 shows that there is a long-term balance between corn prices at the producer level and corn prices at the wholesaler level, wholesaler level and corn prices at the retailer level, producer level and corn prices at the real retailer level. $100 \%$ confidence level. The cointegration test results show that changes in corn prices at the producer level will be followed by changes in corn prices at the wholesaler level in the long run. The price of corn at the producer level and the price of corn at the wholesaler level move together in the long run. This means that if the price of corn at the producer level rises, the price of corn at the wholesaler level also rises. Similarly, the price of corn at the wholesaler level with the price of corn at the retailer level and between the price of corn at the producer level with retailers.

\section{Error Correction Model (ECM) Test}

The ECM test results of corn prices at the producer level with wholesalers, the level of wholesalers with retailers, and the level of producers with retailers are shown in table 3.

Table 4. ECM (Error Correction Model) Test Results between Variable Price Changes at the Producer Level and Price Changes at the Wholesale Trader Level

\begin{tabular}{|c|c|c|c|c|c|c|}
\hline \multirow{2}{*}{ Level } & \multicolumn{6}{|c|}{ Dependent Variable } \\
\hline & Variable & Coefficient & Std. Error & t-Statistic & Prob. & $\mathrm{R}^{2}$ \\
\hline \multirow{3}{*}{ HP and HPG } & $\mathrm{C}$ & 0,581497 & 19,03141 & 0,03055 & 0,9757 & \multirow{3}{*}{0,5860} \\
\hline & $\Delta \mathrm{HG}$ & 0,692598 & 0,066273 & 10,45067 & 0,0000 & \\
\hline & $\operatorname{ECT}(-1)$ & $-0,221039$ & 0,071250 & $-3,10229$ & 0,0027 & \\
\hline \multirow{3}{*}{ HPG and HPP } & $\mathrm{C}$ & 0,918640 & 22,38452 & 0,041039 & 0,9674 & \multirow{3}{*}{0,5195} \\
\hline & $\Delta \mathrm{HPP}$ & 0,620455 & 0,071879 & 8,631883 & 0,0000 & \\
\hline & ECT(-1) & $-0,45097$ & 0,094292 & $-4,78270$ & 0,0000 & \\
\hline \multirow{3}{*}{ HP and HPP } & $\mathrm{C}$ & 0,353356 & 23,33179 & 0,015145 & 0,9880 & \multirow{3}{*}{0,3782} \\
\hline & $\Delta \mathrm{HPP}$ & 0,490164 & 0,074129 & 6,612283 & 0,0000 & \\
\hline & $\mathrm{ECT}(-1)$ & $-0,160935$ & 0,061185 & $-2,63027$ & 0,0102 & \\
\hline
\end{tabular}

Source: Secondary Data (processed)

HP = Manufacturer Price

HPG = Price of Wholesale Traders

HPP = Price of Retailers

Based on table 3 , it can be seen that the probability value ECT $(-1)$ <alpha value (0.1). Based on these results indicate that there is a short-term relationship between the price of corn at the producer level and the price of corn at the wholesaler level, the level of wholesalers and retailers, as well as producers and retailers. ECT (-1) value is the difference in trend expectation of the actual dependent data of the previous period, so the table above explains how the dependent variable adjusts

Agricultural Socio-Economics Journal because of a correction of deviations from trend expectations and how quickly the dependent variable is corrected. The negative sign on the ECT $(-1)$ parameter shows a correction to the deviation from trend expectations, while the large parameters explain the speed of the dependent variable towards the long-term balance (Ekananda, 2015). The negative ECT $(-1)$ value explains that the price will stay away from balance.

The ECM can explain the adjustment of imbalances that occur in the short term so that it can achieve long-term imbalances. The ECT value (0.221039) obtained at producer prices and 
wholesale traders' prices shows that around $22 \%$ of the actual mismatch between the selling price of the producer and the desired level will be adjusted in 2.6 months. The ECT value (0.45097) obtained at wholesaler price prices and retailer prices indicates that around $45 \%$ of the mismatch between the actual selling price of corn at the wholesaler and the desired level will be adjusted at 5.4 months. ECT values
(0.160935) obtained at producer prices and retailer prices indicate that around $16 \%$ of the mismatch between actual and desired prices of corn at the producer level will be adjusted in 1.9 months.

\section{Engle-Granger Causality Test}

Granger causality test is used to determine the effect or relationship of interaction on each variable.

Table 4. Egle-Granger Causality Test Results Corn Prices

\begin{tabular}{lccc}
\hline \multicolumn{1}{c}{ Null Hypothesis } & Obs & F-Statistic & Prob \\
\hline The producer price does not affect the price of wholesale traders & 82 & 2,60405 & 0,0805 \\
Price of wholesale traders does not affect producer prices & & 0,05532 & 0,9462 \\
\hline Price of Wholesalers does not affect the Price of Retailers & 82 & 1,66157 & 0,1966 \\
Price of Retailers does not affect the Price of Wholesalers & & 3,05135 & 0,0531 \\
\hline Producer prices do not affect the prices of retailers & 82 & 0,37328 & 0,6897 \\
Price of Retailers does not affect the Manufacturer Price & & 0,07214 & 0,9305 \\
\hline
\end{tabular}

Source: Secondary Data (processed)

The Engle-Granger causality test results in tables 4 and 5 show that between price variables at the producer level with wholesalers and between price variables at the level of retailers and wholesalers there is a unidirectional causality relationship. The variable producer prices significantly affect the prices of wholesalers, and the variable retailer prices significantly influence the prices of wholesalers. This is indicated by the probability value <alpha $(0,1)$. Whereas the wholesaler price variable does not significantly affect producer prices, wholesale traders 'prices do not significantly affect retailers' prices, producer prices do not significantly affect retailers 'prices, and retailers' prices do not significantly affect producer prices. This is indicated by the probability value> alpha $(0,1)$.

\section{CONCLUSION}

Based on the data analysis that has been done, it can be concluded that the corn market at the producer level with wholesalers, the corn market at the wholesaler level with retailers, the corn market at the producer level with retailers has been integrated in the long term and short term. But in the short term, the coefficient of ECT (-1) is negative which indicates that prices are increasingly away from balance. This was caused by a lack of information on prices received by each market actor.

\section{REFERENCES}

Anindita, Ratya \& Nur Baladina. (2017). Pemasaran Produk Pertanian. Yogyakarta : Penerbit Andi
Asmara, Rosihan \& Ruri Ardhiani. (2010). Integrasi Pasar dalam Sistem Pemasaran Bawang Merah. Agrise, 3, 1412-1425.

Badan Pusat Statistik. (2016). Produksi dan Konsumsi Jagung di Indonesia, Jakarta : Badan Pusat Statistik.

Ekananda, Mahyus. (2015). Ekonometrika Dasar. Bekasi : Mitra Wacana Media.

Gujarati, Damondar N. (2006). Dasar-Dasar Ekonometrika Edisi Ketiga Jilid 2. Jakarta : Penerbit Erlangga.

Kustiari, Reni. (2017). Perilaku Harga Dan Integrasi Pasar Bawang Merah Di Indonesia. Jurnal Agro Ekonomi, 35 (2), 7-87

Murdaningsih, Dwi dan Debbie Sutrisno. (2018). Harga Jagung Anjlok, Mentan Pilih Jual Jagung ke Luar Negeri. (online)( https://republika.co.id/berita/ekonomi/pertania n/18/02/19, diakses pada 16 Desember 2018)

Pioneer. (2017). GPMT : Kebutuhan Jagung Buat Ternak Naik $6 \%$. (online)( https://www.pioneer.com/web/site/indonesia/ GPMT-Kebutuhan-jagung-buat-ternak-naik, diakses pada 13 Desember 2018)

Revania, Lisa. (2014). Analisis Faktor-Faktor Yang Mempengaruhi Impor Jagung Di Indonesia Tahun 1982 - 2012. Jejak. 7(1), 102-112 
Simatupang, P dan J. Situmorang. (1988). Integrasi Pasar dan Keterkaitan Harga Karet Indonesia dengan Singapura. Jurnal Agroekonomi. 7(2), 12-29
Zunaidah, Anggra Dhinatul, et al. (2015). Analisis Integrasi Pasar Apel (Kasus Di Desa Sumbergondo, Kota Batu, Jawa Timur). Habitat, 26, 183-194. 